\title{
Long-distance calls in Neotropical primates
}

\author{
DILMAR A.G. OLIVEIRA ${ }^{1}$ and CÉSAR ADES ${ }^{2}$ \\ ${ }^{1}$ Universidade Regional de Blumenau, Centro de Ciências Exatas e Naturais \\ Cx. Postal 1507, 89010-971 Blumenau, SC, Brasil \\ ${ }^{2}$ Departamento de Psicologia Experimental, Universidade de São Paulo \\ Av. Prof. Mello Moraes 1721, 05508-010 São Paulo, SP, Brasil
}

Manuscript received on January 15, 2004; accepted for publication on February 5, 2004.

\begin{abstract}
Long-distance calls are widespread among primates. Several studies concentrate on such calls in just one or in few species, while few studies have treated more general trends within the order. The common features that usually characterize these vocalizations are related to long-distance propagation of sounds. The proposed functions of primate long-distance calls can be divided into extragroup and intragroup ones. Extragroup functions relate to mate defense, mate attraction or resource defense, while intragroup functions involve group coordination or alarm. Among Neotropical primates, several species perform long-distance calls that seem more related to intragroup coordination, markedly in atelines. Callitrichids present long-distance calls that are employed both in intragroup coordination and intergroup contests or spacing. Examples of extragroup directed long-distance calls are the duets of titi monkeys and the roars and barks of howler monkeys. Considerable complexity and gradation exist in the long-distance call repertoires of some Neotropical primates, and female long-distance calls are probably more important in non-duetting species than usually thought. Future research must focus on larger trends in the evolution of primate long-distance calls, including the phylogeny of calling repertoires and the relationships between form and function in these signals.
\end{abstract}

Key words: long calls, Neotropics, primates, vocal communication.

\section{INTRODUCTION}

Long-distance calls, usually labeled long calls or loud calls, are widespread among primates (Waser 1982, Hohmann and Fruth 1995, Zimmermann 1995, Geissmann 2002). Most works were done on one or a few related species, with few comparative studies within the order. As common properties, most primate long-distance calls have high amplitudes and low frequencies, with most energy usually below $1,5 \mathrm{kHz}$ - features that promote long range transmission of acoustic signals (Mitani and Stuht 1998). As an exception to the low frequency

Correspondence to: Dilmar A.G. de Oliveira

E-mail: dilmar@usp.br rule, several small primates have high frequency loud calls, and explanations range from limitations imposed by small size to the need to avoid the detection of calls by predators (Snowdon 1989, Zimmermann 1995).

Several functions have been proposed to primate long-distance calls, which can be primarily divided into extragroup and intragroup functions. Extragoup functions can be further divided into those related to contests over resources such as food or space, and those related to sexual selection, such as mate guarding or mate attraction. Intragroup functions include alarm and mechanisms of intragroup coordination of activities. In support of the sex- 
ual selection functions of long-distance calls is the fact that adult males make use of long calls more frequently than females. Nonetheless, Wich and Nunn (2002) have found that ecological and social variables related to intergroup resource contests (or intergroup spacing) were more associated with the presence of male loud calls in primate species, while measures of male intra-sexual competition were not.

The use of long-distance calls as alarm vocalizations is seen in primate species whose groups usually disperse over large areas, or when they signal that a predator has been detected - foiling its attempt to attack (Zuberbühler et al. 1997). The use of longdistance calls in group coordination is more typical of species that live in fusion-fission societies or otherwise very dispersed groups. In such species, longrange vocal signals can promote contact and coordination of group activities and movements over long distances (Robinson 1982, Ades and Mendes 1997).

\section{LONG-DISTANCE CALLS IN NEW WORLD MONKEYS}

As forest dwelling species, New World monkeys make a substantial use of the acoustic channel for communication, and both intragroup and intergroup uses of long-distance calls can be found among these primates. With regard to intragroup uses of longdistance calls, New World monkeys present several instances of complex systems of coordination of activities. These are particularly striking in fissionfusion societies as seen in ateline monkeys. The Muriqui Brachyteles arachnoides make use of a complex system of calling exchanges between dispersed group members. Each individual contributes a single emission in a sequence. These emissions are highly variable, with the most intense and longranging ones labeled whines. They probably help to coordinate the activities of the dispersed members of a group (Ades and Mendes 1997). Another ateline, the spider monkeys (genus Ateles), presents at least two forms of loud calls, one more tonal and the other harsher, known as caws, whoops or roars (Eisenberg 1976). These are long syllables found in phrases that can form long bouts several minutes long, and it is likely that they are employed in long range communication between group members.

Another spider monkey call, the whinny, was considered as a cohesion call associated with feeding contexts, but has also been found to have some long range usage. Teixidor and Byrne (1999) found that whinnies of A. geoffroyi emitted in different contexts elicited differential responses from listeners. Nonetheless, the acoustic analysis showed that the calls from different individuals varied in a consistent way according to context for a given individual, but were not consistent between different individuals, pointing out that individual recognition must precede contextual recognition.

Capuchin monkeys have at least one call, the arrawh, that possesses a loud form that can be heard for long distances (Robinson 1982). This loud form is emitted by animals separated from other group members, who usually respond with huh calls and arrawhs, guiding the isolated individual in finding its group.

Several species of callitrichids make use of loud calls when individuals are isolated from their groups, indicating that these calls are used to promote intragroup cohesion. But callitrichid long-distance calls are also used to regulate spacing between neighboring groups (Snowdon 1986, 1989). So, the longdistance calls of callitrichids serve both intragroup and extragroup functions. In Callithrix jacchus, they are known as phee calls, and the forms used in different contexts (intragroup $=$ separation $\times$ intergroup) are distinct, as are the calls produced by members of each sex (Norcross et al. 1999).

Another well known case of typical intergroup usage of long-distance calling by Neotropical primates is found in the duets of titi monkeys (genus Callicebus). Titis are monogamous primates whose duets are made up from a joint emission by the mated pair. In C. moloch, these calls, together with male loud calls, are used in the defense of the boundaries of a territory from other groups (Robinson 1979a, b). Male loud calls are usually emitted while moving toward territory boundaries, and these vocalizations attract neighboring groups. Once the group 
reaches the boundary, the female joins the male in a coordinated duet, and the hearing of duets usually leads to counter-calling by neighboring groups. In C. torquatus (Kinzey and Robinson 1983), loud calls are used in as a site defense mechanism, where a group engages in counter calling on hearing the duets from a neighboring group, but groups avoid male loud calls from other groups. In C. personatus (Price and Piedade 2001) vocal interactions result from encounters between groups but do not lead to exclusive use of home ranges, with great overlapping between neighboring groups. While diverse, all these calling systems result in effective spacing mechanisms between titi monkey groups.

Howler monkeys (genus Alouatta) are well known by their long-distance calls that constitute a complex system. Most studies focused on roars, that are generally seen as a means to mediate intergroup spacing (Altmann 1959, Chivers 1969, Whitehead 1989). But Sekulic (1982) proposed that, in $A$. seniculus, the main function of male roars was to deter outgroup males from entering a troop, acting as a mate defense signal. Roars can last several minutes, but in A. palliata they are always brief, during just some few seconds (Whitehead 1995). Sekulic and Chivers (1986) suggested that the shorter roars of $A$. palliata reflect a lower degree of intergroup sexual competition in this species. As A. palliata is usually considered a basal species in howler monkeys phylogenies (Gregorin 1996), and brief roars are also found in other howler species (Oliveira 2002), it is possible that brief roaring is an ancestral pattern of roaring, preceding the evolution of long, continuous roaring.

The barks are another form of howler monkey long-distance call, used in contexts of varying degrees of alarm or during intergroup encounters (Altmann 1959, Whitehead 1987). Baldwin and Baldwin (1976) believed that, in A. palliata, barks occur in the same kind of contexts that lead to roaring emissions, but with a lower intensity of the eliciting stimulus. Nonetheless, we found that, in $A$. guariba, barks occurred in a greater range of contexts than roars, being found not only in intergroup conflicts but also in moderate to intense alarm contexts, probably acting as a mobbing system of calling (Oliveira 2002).

Howler monkey females also produce a form of long-distance call, the female roar, used in intergroup encounters, probably as a support for group males, and perhaps as a mean to intimidate extragroup females who could otherwise enter their group (Sekulic 1983). Female roars have been found to occur in group separations of A. guariba, probably helping to promote group reunion (Steinmetz 2000, Oliveira 2002). This can be seen as an example of an intragroup use of a usually extragroup-directed long-distance call.

Most species of howler monkeys seem to emit roars with a clear peak of calling around sunrise, the "dawn chorus", usually associated with spontaneous emissions that are used to promote intergroup spacing (Chivers 1969). But in A. pigra roars are emitted in a bimodal pattern, with morning and afternoon peaks of roaring (Cornick and Markowitz 2002). In A. guariba, a dawn chorus is absent (Chiarello 1995, Oliveira 2002), which can result of a greater commitment of roars to direct intergroup contests.

\section{CONCLUSION}

There is a great variability in the production and usage of long-distance calls in Neotropical primates, with several forms described for very distinct species. The long duration and complex structure found in some long-distance calling emissions makes the organization of the calling elements into sequences a topic of great importance that deserves greater attention in future works.

There is also a great gap in our understanding of the evolutionary routes that lead to the diverse calling systems found in primate species. Certainly, we need to search for answers to questions posed by some earlier studies that indicated some relationships between calls of several Neotropical primate species, suggesting that even distantly related species could present similarly structured vocalizations that bear some homologies - functional or even 
in the phylogenetic sense (Moynihan 1967, Eisenberg 1976).

Neotropical primates also show us that a single call can exhibit both intragroup and intergroup functions, as seen in callitrichid's and howler monkey's long-distance calls. The study of variation accompanying the use of such calls in different contexts can force us to review our categorization of vocal categories if we find call variants that have consistently distinct functions.

Another important point is that female longdistance calls, as in the case of howler monkeys, atelines and callitrichids, are also important in nonduetting species. Additional work has to be done to understand the evolution and functions of female long-distance calls in primates, usually eclipsed by the most conspicuous and widespread male loud calls.

Finally, long-distance calls can provide greater insights into the more general issue of the evolution of communicative signals. They face the multiple and even conflicting tasks of traveling for long distances, with minimal loss of information and achieving a specific function, both of which impose constraints in the form of a signal. So, their study can contribute to our knowledge of the relationships between form and function in signals, still poorly explored in primate vocal systems (Owren and Rendall 2001).

\section{ACKNOWLEDGMENTS}

The authors wish to thank Dr. Jacques Vielliard and Dr. Maria Luisa da Silva for their help during the XIX IBAC, and Dr. Dietmar Todt and Dr. Francisco Mendes for their invitation to take part in the symposium that originated this work. Dr. Todt and an anonymous referee have also made helpful comments. The support of the Brazilian funding agencies CNPq and FAPESP was much appreciated.

\section{RESUMO}

Chamados de longo alcance são comuns em primatas. Muitas pesquisas enfocaram tais vocalizações em uma única ou em poucas espécies, enquanto poucos estudos lidaram com padrões mais gerais dentro da ordem. As características comuns que geralmente distinguem estas vocalizações são relacionadas com a transmissão de sons a longa distância. As funções propostas para estas vocalizações podem ser divididas entre intragrupais e extragrupais. Funções extragrupais se relacionam com a defesa e atração de parceiros sexuais ou com a defesa de recursos, enquanto as funções intragrupais envolvem coordenação intragrupal ou alarme. Entre os primatas neotropicais, diversas espécies exibem chamados de longo alcance que parecem mais associados à coordenação intragrupal, principalmente entre os atelinos. Os calitriquídeos possuem chamados de longo alcance que são usados tanto na coordenação intragrupal como em disputas ou espaçamento entre grupos. Exemplos de chamados de longo alcance extragrupais são os duetos dos sauás e os rugidos e latidos dos bugios. Existe considerável complexidade e gradação nos repertórios de chamados de longo alcance de alguns primatas neotropicais, sendo que os chamados das fêmeas são provavelmente mais importantes do que se costuma pensar, em espécies que não emitem duetos. Estudos futuros devem enfocar padrões predominantes na evolução de chamados de longo alcance em primatas, incluindo a filogênese dos repertórios de chamados e as relações entre forma e função nestes sinais.

Palavras-chave: chamados de longo alcance, neotrópicos, primatas, comunicação vocal.

\section{REFERENCES}

Ades C And Mendes FDC. 1997. Uma aproximação às vocalizações do muriqui (Brachyteles arachnoides). Temas em Psicologia 3: 135-149.

Altmann SA. 1959. Field observations on a howling monkey society. J Mammal 40: 317-330.

BALDWIN JD AND BALDWIN JI. 1976. Vocalizations of howler monkeys (Alouatta palliata) in Southwestern Panama. Folia Primatol 26: 81-108.

Chiarello AG. 1995. Role of loud calls in Brown Howlers, Alouatta fusca. Am J Primatol 36: 213-222.

Chivers DJ. 1969. On the daily behaviour and spacing of howling monkey groups. Folia Primatol 10: 48-102.

Cornick LA and Markowitz H. 2002. Diurnal vo- 
cal patterns of the Black Howler Monkey (Alouatta pigra) at Lamanai, Belize. J Mammal 83: 159-166.

EISENBERG JF. 1976. Communication mechanisms and social integration in the Black Spider Monkey, Ateles fusciceps robustus, and related species. Smiths Contr Zool 213: 1-108.

Geissmann T. 2002. Duet-splitting and the evolution of gibbon songs. Biol Rev 77: 57-76.

GregORIN R. 1996. Variação geográfica e taxonomia das espécies brasileiras do gênero Alouatta Lacépède, 1799 (Primates, Atelidae). Master Thesis. São Paulo: Universidade de São Paulo, 226 p.

Hohmann G AND Fruth B. 1995. Long-distance calls in great apes: sex differences and social correlates. In: Zimmermann E et al. (Eds), Current topics in primate vocal communication. New York: Plenum Press, p. 161-184.

KinZey WG AND Robinson JG. 1983. Intergroup loud calls, range size, and spacing in Callicebus torquatus. Am J Phys Anthropol 60: 539-544.

Mitani JC and Stuht J. 1998. The evolution of nonhuman primate loud calls: acoustic adaptation for long-distance transmission. Primates 39: 171-182.

Moynihan M. 1967. Comparative aspects of communication in New World primates. In: MorRIS D (Ed), Primate ethology. Chicago: Aldine Publishing Company, p. 236-266.

Norcross JL, Newman JD and Cofrancesco LM. 1999. Context and sex differences exist in the acoustic structure of phee calls by newly-paired Common Marmosets (Callithrix jacchus). Am J Primatol 49: 165-181.

Oliveira DAG. 2002. Vocalizações de longo alcance de Alouatta fusca clamitans e Alouatta belzebul belzebul: estrutura e contextos. Doctoral Thesis. São Paulo: Universidade de São Paulo, 155 p.

Owren MJ And Rendall D. 2001. Sound on the rebound: bringing form and function back to the forefront in understanding nonhuman primate vocal signaling. Evol Anthropol 10: 58-71.

Price EC ANd Piedade HM. 2001. Ranging behaviors and intraspecific relationships of Masked Titi Monkeys (Callicebus personatus personatus). Am J Primatol 53: 87-92.

RoBINSON JG. 1979a. An analysis of the organization of vocal communication in the titi monkey Callicebus moloch. Z Tierpsychol 49: 381-405.

RobInson JG. 1979b. Vocal regulation of use of space by groups of titi monkeys Callicebus moloch. Behav Ecol Sociobiol 5: 1-15.

RobInson JG. 1982. Vocal systems regulating withingroup spacing. In: SNOwdon CT et al. (Eds), Primate communication. Cambridge: Cambridge University Press, p. 94-116.

SeKulic R. 1982. The function of howling in Red Howler Monkeys (Alouatta seniculus). Behaviour 81: 38-54.

SEKULIC R. 1983. The effect of female calls on male howling in Red Howler Monkeys (Alouatta seniculus). Int J Primatol 4: 291-305.

Sekulic R And Chivers DJ. 1986. The significance of call duration in howler monkeys. Int J Primatol 7: 183-190.

SNOwdon CT. 1986. Vocal communication. In: MitCHELl G AND ERwin J (Eds), Comparative primate biology, Vol. 2A: Behaviour, conservation and ecology. New York: Alan R. Liss, p. 495-530.

SNOwdON CT. 1989. Vocal communication in New World monkeys. J Hum Evol 18: 611-633.

STEINMETz S. 2000. Ecologia e comportamento do bugio (Alouatta fusca clamitans, Atelidae - Primates) no Parque Estadual Intervales - SP. Master Thesis. São Paulo: Universidade de São Paulo, 101 p.

TeIXIDOR P AND Byrne RW. 1999. The 'whinny' of spider monkeys: individual recognition before situational meaning. Behaviour 136: 279-308.

WASER PM. 1982. The evolution of male loud calls among mangabeys and baboons. In: SNOwdon CT et al. (Eds), Primate communication. Cambridge: Cambridge University Press, p. 117-143.

WhiteHEAD JM. 1987. Vocally mediated reciprocity between neighbouring groups of Mantled Howling Monkeys, Alouatta palliata palliata. Anim Behav 35: 1615-1627.

WhiteheAd JM. 1989. The effect of the location of a simulated intruder on responses to long-distance vocalizations of Mantled Howling Monkeys, Alouatta palliata palliata. Behaviour 108: 73-103.

Whitehead JM. 1995. Vox Alouattinae: a preliminary survey of the acoustic characteristics of long distance calls of howling monkeys. Int J Primatol 16: 121-144. 
Wich SA AND NunN CL. 2002. Do male "long-distance calls" function in mate defense? A comparative study of long-distance calls in primates. Behav Ecol Sociobiol 52: 474-484.

ZimMERMANN E. 1995. Loud calls in nocturnal prosimians: structure, evolution and ontogeny. In: ZIMMERMANN E et al. (Eds), Current topics in primate vocal communication. New York: Plenum Press, p. 47-72.
Zuberbühler K, Nö̈ R AND Seyfarth RM. 1997. Diana monkey long-distance calls: messages for conspecifics and predators. Anim Behav 53: 589-604. 